\title{
PERAN BRAND TRUST MEMEDIASI HUBUNGAN BRAND IMAGE DENGAN BRAND LOYALTY (Studi Pada Konsumen Iphone di Kota Denpasar)
}

\author{
Yolanda Rodiques ${ }^{1}$ \\ Gede Bayu Rahanatha ${ }^{2}$ \\ ${ }^{1,2}$ Fakultas Ekonomi dan Bisnis Universitas Udayana (Unud), Bali Indonesia \\ email : yolanda_rodiques@yahoo.co.id
}

\begin{abstract}
ABSTRAK
Penelitian ini bertujuan untuk menjelaskan peran brand trust dalam memediasi hubungan brand image dengan brand loyalty. Penelitian dilakukan di kota Denpasar dengan jumlah sampel sebanyak 100 responden pengguna smartphone Iphone yang telah melakukan pembelian berulang (minimal 2 kali) terhadap produk tersebut. Sampel ditentukan menggunakan model non-probability sampling, dengan teknik purposive sampling. Teknik analisis data yang digunakan adalah analisis jalur dan uji sobel. Hasil penelitian menunjukkan bahwa seluruh hipotesis diterima. Brand image berpengaruh positif dan signifikan terhadap brand trust, brand image berpengaruh positif dan signifikan terhadap brand loyalty, brand trust berpengaruh positif dan signifikan terhadap brand loyalty, brand trust berpengaruh positif dan signifikan memediasi hubungan brand image dengan brand loyalty. Perusahaan diharapkan kedepannya harus melalukan pemasaran campaign (iklan) yang maksimal dan inovatif untuk menunjang image kelas sosial di mata masyarakat, menumbuhkan tingkat kepercayaan konnsumen terhadap keamanan produknya yang digali dari pandangan, persepsi, pengalaman positif terhadap keamanan produk, kualitas produk \& jasa dan dapat mempertahankan konsumen loyalnya.
\end{abstract}

Kata kunci: brand image, brand trust, brand loyalty

\begin{abstract}
This study aims to explain the role of brand trust in mediating the relationship of brand image with brand loyalty. The study was made in Denpasar city with the number of samples of 100 respondens Iphone smartphone users who have repurchases (at least 2 times of purchases) of the product. The sample is determined using non-probability sampling model, with purposive sampling technique. Data analysis technique used is path analysis and sobel test. The results showed that all hypotheses were accepted. Brand image has a positive and significant influence to brand trust, brand image has a positive and significant effect to brand loyalty, brand trust has a positive and significant influence to brand loyalty, brand trust has a positive and significant effect on mediating the relationship of brand image with brand loyalty. In the future, the company is expected to launch a maximum and innovative marketing campaign (advertisement) to raise the social class image of the Iphone users in the society and increase the level of consumer confidence in regard to the security aspect of the Iphone products
\end{abstract}

Keywords: brand image, brand trust, brand loyalty 


\section{PENDAHULUAN}

Perkembangan globalisasi yang kian menyeluruh diberbagai belahan negara memberikan pengaruh pada kemajuan teknologi. Keadaan ini tidak terlepas dari aktivitas masyarakat yang kerap kali ditunjang dengan teknologi informasi itu sendiri. Perkembangan teknologi membawa dampak terhadap ketatnya persaingan para perusahan atau produsen untuk bersaing secara kompetitif dalam hal menciptakan dan mempertahankan konsumennya yang loyal dan salah satunya adalah persaingan antar merek.

Keberadaan smartphone merupakan salah satu dampak dari perkembangan teknologi yang semakin maju dan kompetitif tersebut. Penggunaan smartphone semakin meningkat dari tahun ke tahun, termasuk di Indonesia. Indonesia dengan jumlah penduduk yang mencapai 250 juta jiwa menjadikan smartphone menjadi target pasar yang besar. Hal tersebut dapat dilihat pada Gambar 1, sebagai berikut:

\section{Gambar 1. Jumlah Pengguna Smartphone di Indonesia (dalam juta)}

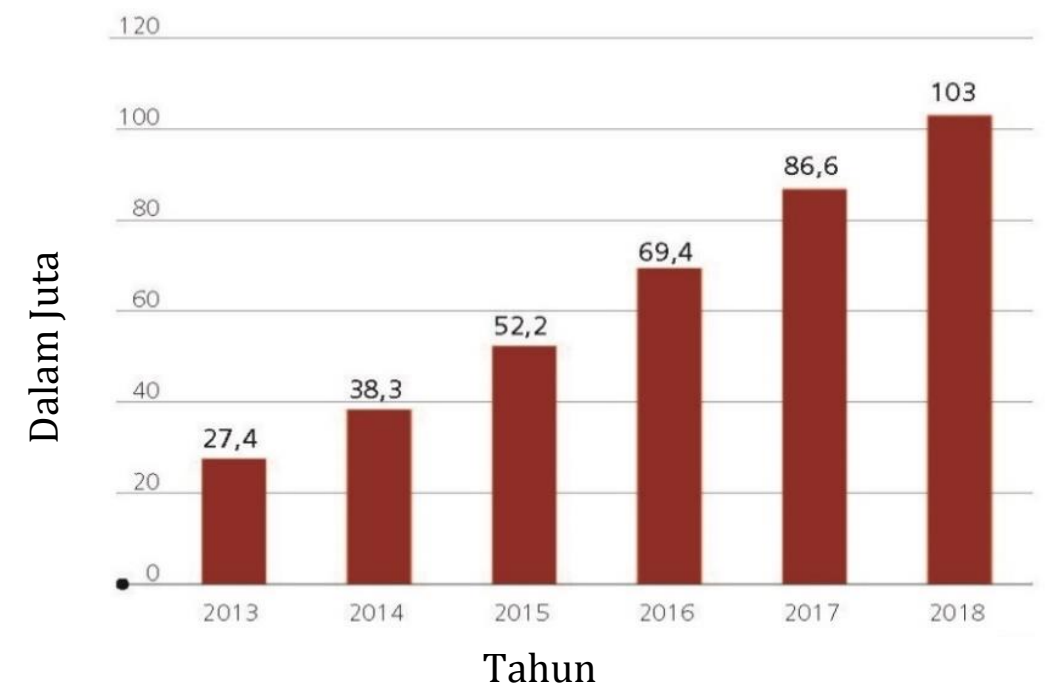

Sumber : Lembaga Riset Digital Marketing, Emarketer, 2015. 
Data pada Gambar 1, menjelaskan bahwa terdapat peningkatan pengguna smartphone di Indonesia, diperkirakan tahun 2018, Indonesia menjadi peringkat empat dalam pengguna aktif smartphone dengan total pengguna mencapai 100 juta orang (Tempo, 2015).

Perusahaan smartphone mempelajari perilaku konsumennya dalam konsumsi penggunaan smartphone terhadap suatu merek tertentu. Adanya brand image atas suatu produk smartphone akan sangat memudahkan konsumen dalam pengambilan keputusan untuk membeli. Brand image dapat menciptakan kepercayaan atas suatu produk. Brand trust (kepercayaan merek) adalah harapan akan kehandalan dan intensi baik merek (Delgado, 2003). Kepercayaan merek akan mendorong perilaku pembelian ulang dan loyalitas terhadap sebuah merek.

Brand image yang positif dapat meningkatkan kemungkinan pilihan terhadap sebuah brand (Keller, 2003). Konsumen yang loyal pada umumnya lebih percaya dengan brand produk yang telah dikenalnya, dan tidak mudah beralih menggunakan brand lain. Dalam menciptakan suatu loyalitas dalam sebuah merek, pemasar terlebih dahulu harus membangun kepercayaan konsumen terhadap merek (Lau dan Lee, 1999).

Loyalitas pelanggan merupakan asset yang berharga bagi setiap perusahaan. Loyalitas merek adalah perilaku niat untuk membeli sebuah produk dan mendorong orang lain untuk melakukan hal yang sama, yang mendatangkan profit bagi perusahaan (Lau dan Lee dalam Rizal dkk., 2012). Kepercayaan terhadap merek merupakan hal yang penting dan menjadi salah satu factor kunci dalam mengembangkan loyalitas terhadap citra merek. 
E-Jurnal Manajemen Unud, Vol.-, No. -, 2018 :-

Apple Inc. merupakan perusahaan yang bergerak dibidang consumer electronic salah satunya adalah produk smartphone, Iphone. Produk Iphone merupakan produk dengan citra yang kuat. Fenomena ini menggambarkan bahwa Iphone mampu meyakinkan konsumen sehingga pelanggan percaya dan loyal terhadap Iphone. Kepercayaan ini tidak terlepas dari keunggulan produk. Apple selalu menjaga kualitas produk dan terus melakukan inovasi. Meskipun pasar smartphone didominasi oleh Android, nyatanya Apple selalu menjadi trend center dalam pengembangan aplikasi. Tampilan ponsel milik Apple memiliki desian unik yang merupakan ciri khas dari produk - produk keluaran Apple (Liputan6, 2016).

Pada awal 2017, penjualan Iphone meningkat menjadi 78 juta unit. Hal ini dapat disebabkan oleh peluncuran Iphone 7 dan 7+ yang diterima positif oleh masyarakat (Kompas.com, 2017). Tingginya persaingan smartphone, menyebabkan banyak pesaing menawarka harga yang lebih terjangkau seperti Oppo, Sony, Lenovo, bahkan Nokia. Meskipun hal tersebut terjadi, Iphone tetap menjadi incaran oleh konsumen ditengah tingginya persaingan smartphone di Indonesia.

Fenomena yang berkembang menunjukan bahwa Iphone masih mampu untuk mempertahankan konsumen atau pelangganya di tengah ketatnya persaingan yang dihadapi oleh beragam perusahaan smartphone. Konsumen yang loyal dikarenakan pengalaman yang baik yang telah dirasakan oleh konsumen pada produk tersebut sehingga yakin dan percaya menggunakan produk Iphone. Pada akhirnya, kepercayaan terhadap merek Apple semakin tinggi hingga terbentuknya loyalitas pada produk smartphone tersebut. 
Survei Asosiasi Pengguna Jasa Internet Indonesia (APJII) menunjukkan bahwa pengguna internet di Indonesia terus bertambah. Pengguna smartphone di Indonesia terkonsentrasi di Pulau Jawa dan Bali sebesar 59\% (detik.com, 2015). Berdasarkan kondisi tersebut, peluang perusahaan menjadikan Bali menjadi salah satu target perkembangan industri teknologi dan komunikasi, khususnya Denpasar sebagai ibukota dan menjadi sentral perkembangan teknologi Bali.

Penelitian oleh Maliyah (2015) mengungkapkan brand image tidak berpengaruh terhadap brand trust. Hal serupa ditemukan pada penelitian yang dilakukan oleh Hadi dan Sumarto (2010) dan Sibagariang dan Nursanti (2010) menyatakan bahwa brand image tidak memiliki pengaruh positif terhadapobrand loyalty. Penelitian Noor (2014) menyatakan bahwa brand image berpengaruh positif terhadap brand loyalty namun tidak signifikan. Hasil serupa juga ditemukan pada penelitian oleh Satyadharma (2014) mengungkapkano bahwa brand trust tidak memiliki pengaruh yang positif terhadap brand loyalty. Harnoto (2013) menyatakan bahwa kepercayaan tidak terbukti berpengaruh positif terhadap loyalitas pelanggan. Akan tetapi, brand trust berpengaruh positif terhadap brand loyalty melalui brand trust sebagai variabel mediasi dalam penelitian SB. Handayani dan Ida Martini (2015).

Berdasarkan latar belakang permasalahan yang telah disampaikan dan acuan studi-studi terdahulu, maka penelitian ini membahas hubungan antara tiga variabel yaitu brand image, brand trust, dan brand loyalty pada konsumen Iphone di Kota Denpasar. Dari latar belakang tersebut maka rumusan penelitian yang dapat disusun adalah bagaimana pengaruh brand image terhadap brand trust pada konsumen 
E-Jurnal Manajemen Unud, Vol.-, No. -, 2018 :-

Iphone, bagaimana pengaruh brand image dan brand trust terhadap brand loyalty pada konsumen Iphone dan bagaimana peran brand trust memediasi hubungan brand image dengan brand loyalty pada konsumen Iphone di Kota Denpasar?

Sesuai dengan rumusan masalah tersebut, maka tujuan dari penulisan penelitian ini adalah untuk menjelaskan pengaruh brand image terhadap brand trust pada konsumen Iphone, menjelaskan pengaruh brand image dan brand trust terhadap brand loyalty pada konsumen Iphone dan menjelaskan peran brand trust memediasi hubungan brand image dengan brand loyalty pada konsumen Iphone di Kota Denpasar.

Penelitian ini memiliki kegunaan teoritis yang dapat dijadikan sebagai referensi terkait peran brand trust sebagai pemediasi hubungan brand image dengan brand loyalty dan kegunaan praktis yang memberikan informasi dan bahan pertimbangan pengambilan keputusan bagi pengusaha terutama yang bergerak dalam bidang customer electric, penelitian ini diharapkan dapat memberi informasi mengenai peran brand trust memediasi hubungan brand image dengan brand loyalty.

Merek adalah nama atau lambang yang diguakan untuk mengidentifikasi barang atau jasa dari salah satu penjual, sebuah merek dapat menjadi diferensiasi dari pesaing (Kotler \& Keller, 2012:263). Merek memiliki enam level pengertian (Kotler, 2012:272), diantaranya atribut, berupa merek dapat mengingatkan pada atibut. Manfaat, merupakan manfaat fungsional dan emosional. Nilai, berupa merek dapat menyatakan sesuatu tentang nilai produsen. Budaya, diartikan merek dapat mewakili budaya tertentu. Kepribadian, diartikan bahwa merek dapat 
mencerminkan kepribadian tertentu. Pemakai, diartikan bahwa merek dapat menggambarkan jenis konsumen yang menggunakan merek tersebut.

Citra merek adalah seperangkat keyakinan konsumen mengenai merek tertentu (Kotler dan Amstrong, 2001:225). "Brand association is anything linked in memory to a brand". Pengertian ini menunjukan bahwa asosiasi merek adalah sesuatu yang berhubungan dengan merek dalam ingatan konsumen (Aaker, 1991:109). Jadi dapat disimpulkan bahwa brand image merupakan representasi dari keseluruhan persepsi terhadap merek dan dibentuk dari informasi dan pengalaman terhadap merek tersebut. Menurut Keller (1993:3) faktor-faktor yang membentuk brand image adalah: Kekuatan asosiasi merek (strength of brand association), Keuntungan asosiasi merek (favourability of brand association), Keunikan asosiasi merek (Uniqueness Of brand association). Menurut Kotler (2001:401) citra harus dibangun melalui seluruh media yang ada serta berkelanjutan dan pesan tersebut dapat disampaikan melalui lambang, media atau visual, suasana, serta acara.

Kepercayaan merek adalah persepsi akan kehandalan dari sudut pandang konsumen didasarkan pada pengalaman, atau lebih pada urutan-urutan transaksi atau interaksi yang dicirikan oleh terpenuhinya harapan akan kinerja produk dan kepuasan (Riset Costabile dalam Handayani, 2015). Kepercayaan terbangun karena adanya harapan bahwa pihak lain akan bertindak sesuai dengan kebutuhan dan keinginan konsumen. Kepercayaan melibatkan kesediaan seseorang untuk bertingkah laku tertentu karena keyakinan bahwa mitranya akan memberikan apa yang ia harapkan dan suatu harapan yang umumnya dimiliki seseorang bahwa kata, janji atau pernyataan orang lain dapat dipercaya (Barnes, 2003:148). Kepercayaan 
E-Jurnal Manajemen Unud, Vol.-, No. -, 2018 :-

pada suatu merek (brand trust) menggambarkan suatu komponen yang penting dari penempatan internal atau sikap yang diasosiasikan dengan loyalitas merek. (Lau dan Lee, 1999). Oleh karena itu, pemahaman yang lebih sempurna tentang loyalitas terhadap suatu merek tidak akan tercapai tanpa adanya penjelasan mengenai kepercayaan merek (brand trust). Karakteristik merek, karakteristik perusahaan dan karakteristik hubungan pelanggan dengan merek merupakan prediktor penting kepercayaan pelanggan terhadap merek yang pada akhirnya akan dapat mengarah pada loyalitas pelanggan pada merek tersebut.

Aaker (1991:56) mendefinisikan loyalitas merek (brand loyalty) sebagai suatu ukuran keterkaitan pelanggan kepada sebuah merek. Ukuran ini mampu memberikan gambaran tentang mungkin tidaknya seorang pelanggan beralih ke merek lain yang ditawarkan oleh kompetitor, terutama jika pada merek tersebut didapati adanya perubahan, baik menyangkut harga ataupun atribut lainnya. Seorang pelanggan yang sangat loyal kepada suatu merek tidak akan dengan mudah memindahkan pembeliannya ke merek lain, apa pun yang terjadi dengan merek tersebut. Bila loyalitas pelanggan terhadap suatu merek meningkat, kerentanan kelompok pelanggan tersebut dari ancaman dan serangan merek produk pesaing dapat dikurangi. Loyalitas pelanggan adalah dorongan perilaku untuk melakukan pembelian secara berulang-ulang dan untuk membangun kesetiaan pelanggan terhadap suatu produk/jasa yang dihasilkan oleh badan usaha tersebut membutuhkan waktu yang lama melalui suatu proses pembelian berulang-ulang tersebut (Gibson, 2005:75). Pelanggan dikatakan setia atau loyal apabila pelanggan tersebut menujukkan perilaku pembelian secara teratur atau terdapat suatu kondisi 
dimana mewajibkan pelanggan membeli paling sedikit dua kali dalam selang waktu tertentu. Upaya memberikan kepuasan dilakukan untuk mempengaruhi sikap pelanggan, sedangkan konsep loyalitas pelanggan lebih berkaitan dengan perilaku dari pada sikap dari pelanggan (Griffin, 2005:46).

Penelitian Bastian (2014), Chanda, dan Garima (2014), Chinomona (2016), menemukan bahwa brand image memiliki pengaruh positif dan signifikan positif terhadap brand trust. Berdasarkan hasil empiris dan temuan pada penelitian sebelumnya, hipotesis yang dapat diajukan dalam penelitian ini adalah:

$\mathrm{H}_{1} \quad$ : Brand image memiliki pengaruh yang positif dan signifikan terhadap brand trust

Penelitian oleh Alhaddad (2015), Dewi dan Suasana (2014), Saputri dan Pranata (2014), serta Salim dan Dharmayanti (2014) menyatakan bahwa brand image memiliki pengaruh positif yang signifikan terhadap brand loyalty. Berdasarkan hasil empiris dan temuan pada penelitian sebelumnya, hipotesis yang dapat diajukan dalam penelitian ini adalah:

$\mathrm{H}_{2} \quad$ : Brand image memiliki pengaruh yang positif dan signifikan terhadap brand loyalty

Penelitian Sirashmukh et al. (2002), Kabadayi (2012), Geçti dan Zengin (2013), Ahmed et al. (2014) dan Putra (2014) menyatakan bahwa brand trust memiliki pengaruh positif dan signifikan terhadap brand loyalty. Berdasarkan hasil empiris dan temuan pada penelitian sebelumnya, hipotesis yang dapat diajukan dalam penelitian ini adalah: 
E-Jurnal Manajemen Unud, Vol.-, No. -, 2018 :-

$\mathrm{H}_{3} \quad$ : Brand trust memiliki pengaruh yang positif dan signifikan terhadap brand loyalty

Penelitian oleh Handayani dan Ida Martini (2015) mengemukakan bahwa brand trust memediasi hubungan antara brand image terhadap brand loyalty. Brand trust terbukti mampu menjadi variabel mediasi dalam penelitian ini. Berdasarkan hasil empiris dan temuan pada penelitian sebelumnya, hipotesis yang dapat diajukan dalam penelitian ini adalah:

$\mathrm{H}_{4} \quad$ : Brand trust mampu memediasi hubungan brand image dengan brand loyalty

Berdasarkan kajian teoritis dan empiris yang telah dipaparkan sebelumnya, maka untuk memperjelas arah pada penelitian ini maka dapat dilihat kerangka konseptual sebagai berikut:

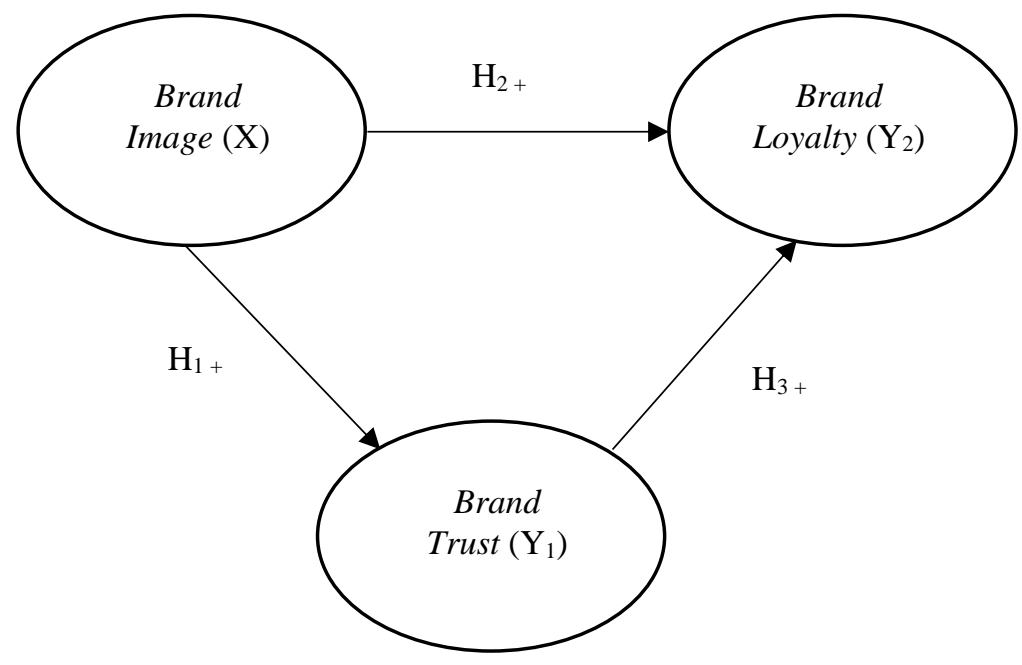

Gambar 2. Kerangka Konseptual

\section{METODE PENELITIAN}


Desain penelitian yang digunakan dalam penelitian ini adalah penelitian asosiatif dengan tujuan untuk mengetahui hubungan antara variabel brand image, brand trust dan brand loyalty pada produk Iphone. Lokasi pada penelitian ini dilakukan di Kota Denpasar, kota ini dipilih karena intensitas masyarakat dalam menggunakan smartphone yang cukup tinggi. Subjek dalam penelitian ini difokuskan terhadap pengguna smartphone Iphone, sedangkan yang menjadi objek dalam penelitian ini adalah peran brand trust memediasi brand image terhadap brand loyalty konsumen smartphone Iphone di Denpasar.

Penelitian ini menggunakan 3 jenis variabel, yaitu variabel independen berupa brand image $(\mathrm{X})$, variabel mediasi berupa brand trust $\left(\mathrm{Y}_{1}\right)$ dan variabel dependen berupa brand loyalty $\left(\mathrm{Y}_{2}\right)$. Brand Image merupakan persepsi konsumen tentang merek Iphone yang ada dalam benak konsumen. Brand Trust (kepercayaan merek) adalah keyakinan konsumen terhadap merek Iphone. Sedangkan Brand loyalty adalah tingkatan dimana sikap positif pelanggan Iphone untuk terus melanjutkan membeli produk dengan Iphone dimasa yang akan datang. Indikator dalam mengukut ketiga variabel tersebut disajikan pada Tabel 1,

Tabel 1.

Indikator Variabel Penelitian

\begin{tabular}{lllc}
\hline \multicolumn{1}{c}{ Variabel } & \multicolumn{1}{c}{ Indikator } & Sumber \\
\hline Brand & 1) & Experiental Benefit $(\mathrm{X} .1)$ & Salim dan \\
Image $(X)$ & 2) & Functional Benefit $(\mathrm{X} .2)$ & Dharmayanti \\
& 3) & Social Benefit $(\mathrm{X} .3)$ & $(2014)$ \\
& 4) & Apperance Enchances $(\mathrm{X} .4)$ & Geçti dan Zengin \\
Brand Trust & 1) & Percaya pada merek $\left(\mathrm{Y}_{1 \cdot 1}\right)$ & $(2013)$ \\
$\left(Y_{1}\right)$ & 2) & Merek memberi rasa aman $\left(\mathrm{Y}_{1.2}\right)$ & \\
& 3) & Merek jujur kepada konsumen $\left(\mathrm{Y}_{1 \cdot 3}\right)$ & Griffin $(2005)$ \\
Brand & 1) & Melakukan pembelian ulang $\left(\mathrm{Y}_{2 \cdot 1}\right)$ & \\
Loyalty $\left(Y_{2}\right)$ & 2) & Memberikan referensi pada orang lain $\left(\mathrm{Y}_{2 \cdot 2}\right)$ & \\
& 3) & Menunjukkan kekebalan terhadap pesaing $\left(\mathrm{Y}_{2 \cdot 3}\right)$ & \\
\hline
\end{tabular}


Jenis data yang digunakan dibedakan menjadi dua bagian yaitu data kualitatif berupa pendapat responden yang diuraikan dalam kuesioner dan data kuantitatif berupa hasil dari pengolahan kuesioner. Sumber data dalam penelitian ini berasal dari sumber primer berupa data tentang jawaban responden atas item-item pernyataan atau pertanyaan kuesioner penelitian dari data konsumen smartphone Iphone di Denpasar, sedangkan sumber sekunder berupa data dari dokumentasi perusahaan, publikasi pemerintah, analisis industri oleh media, situs Web, internet, buku-buku, literatur dan bacaan yang berkaitan dengan konsumen smartphone Iphone.

Populasi yang digunakan dalam penelitian ini adalah konsumen smartphone Iphone di Kota Denpasar yang tidak diketahui jumlah pastinya, karena kondisi ini maka ditentukanlah sampel yang terlibat dalam penelitian dengan model nonprobability sampling, dengan teknik purposive sampling. Kriteria tersebut diantaranya responden berdomisili di kota Denpasar, responden merupakan pengguna smarphone Iphone, responden yang telah melakukan pembelian minimal 2 kali pembelian terhadap smartphone Iphone, responden memiliki jenjang pendidikan SMA dan berusia minimal 18 tahun dengan pertimbangan dianggap memahami pernyataan dan mampu menjawab kuesioner dengan baik dan benar

Jumlah sampel yang ideal adalah 5-10 kali jumlah variabel indikator yang digunakan (Ferdinand, 2002:47). Melihat jumlah indikator yang digunakan berjumlah 10, maka jumlah responden yang terlibat berada pada kisaran 50-100 sampel. Jadi, sampel berjumlah 100 responden yang akan diteliti dalam penelitian ini telah memenuhi syarat yang ditentukan. 
Metode pengumpulan data dalam penelitian ini adalah menggunakan metode survey dengan penyebaran kuesioner secara langsung kepada responden. Kuesioner adalah instrumen pengumpulan data yang digunakan. Selanjutnya kuesioner akan diukur dengan menggunakan skala Likert dengan rincian penilaian seperti disajkan dalam Tabel 2, sebagai berikut.

Tabel 2.

Penentuan Skor Jawaban Responden

\begin{tabular}{ccc}
\hline Jawaban & Kode & Skor \\
\hline Sangat Setuju & SS & 5 \\
Setuju & S & 4 \\
Cukup Setuju & CS & 3 \\
Tidak Setuju & TS & 2 \\
Sangat Tidak Setuju & STS & 1 \\
\hline
\end{tabular}

Sumber: Sugiyono, 2016

Kuesioner yang akan digunakan sebelum digunakan diuji kelayakannya dengan uji validitas dan reliabilitas. Uji validitas digunakan untuk mengetahui valid tidaknya suatu kuesioner. Suatu kuesioner dikatakan valid jika koefisien korelasi $\geq$ 0,30. Uji reliabilitas dilakukan untuk mengetahui konsistensi indikator dalam kuesioner sebagai alat ukut. Kuesioner dapat dikatakan reliable jika nilai Cronbach Alfa $>0,6$.

Teknik analisis data yang digunakan adalah teknik analisis deskriptif dan inferensial. Analisis deskripitf digunakan untuk mendeskripsikan karakteristik responden dan variabel-variabel penelitian, sedangkan analisis inferensial digunakan untuk mengetahui kebenaran dari hipotesis yang telah disusun. Analisis inferensial yang digunakan berupa analisis factor konfirmatori, uji asumsi klasik dan analisis jalur.

Analisis faktor konfirmatori adalah salah satu metode analisis multivariate yang dapat digunakan untuk menginformasi apakah model pengukuran yang 
dibangun sesuai dengan yang dihipotesiskan. (Ghozali, 2013:399). Hasil analisis dari teknik ini disebut measurement control. Measurement control mengukur kuatnya struktur dari dimensi - dimensi yang dibentuk sebuah faktor.

Tabel 3.

Confirmatory Faktor Analysis

\begin{tabular}{clc}
\hline No. & Indikator & Nilai Koefisien \\
\hline 1. & KMO & $\geq 0,5$ \\
2. & MSA & $\geq 0,5$ \\
3. PCA & $\geq 0,5$ \\
4. & Total Variance Explained & $\geq 0,6$ \\
5. & Loading Faktor & $\geq 0,5$ \\
\hline \multicolumn{2}{l}{ Sumber: Ghozali, 2013 }
\end{tabular}

Suatu model secara teoritis akan menghasilkan nilai parameter penduga yang tepat bila memenuhi persyaratan asumsi klasik regresi, meliputi uji normalitas, multikolinieritas dan heteroskedastisitas. Uji normalitas bertujuan untuk mengetahui veriabel residual memiliki distribusi normal, uji multikolinieritas bertujuan dalam mengetahui ada tidaknya korelasi antar variabel independen dan uji heteroskedastisitas bertujuan untuk menguji apakah dalam model regresi terjadi ketidaksamaan varian dari residual satu pengamatan ke pengamatan lainnya.

Teknik analisis data yang digunakan adalah teknik analisis jalur. Analisis jalur merupakan perluasan dari analisis regresi linier berganda untuk menaksir hubungan kausalitas antar variabel yang telah ditetapkan sebelumnya berdasarkan teori (Ghozali, 2013: 249). Pengujian hipotesis mediasi dilakukan dengan dengan Uji Sobel berupa menguji kekuatan tidak langsung variabel independen (X) kepada variabel dependen $\left(\mathrm{Y}_{2}\right)$ melalui variabel mediasi $\left(\mathrm{Y}_{1}\right)$.

\section{HASIL DAN PEMBAHASAN}

Smartphone Iphone merupakan smartphone yang diproduksi oleh perusahaan Apple Inc. Perusahaan Apple Inc. didirikan pada tanggal 1 April 1976. Perusahaan 
multinasional tersebut berpusat di Silicon Valley, Cupertino, California yang bergerak dalam bidang perancangan, pengembangan, dan penjualan barang-barang diantaranya adalah consumer electric, perangkat lunak komputer, serta komputer pribadi.

Responden yang diambil dalam penelitian ini berjumlah 100 orang responden, yang diperoleh dari penyebaran kuesioner secara langsung. Karakteristik responden penelitian ini disajikan dalam Tabel 4, sebagai berikut:

Tabel 4.

Karakteristik Responden

\begin{tabular}{|c|c|c|c|c|}
\hline No. & Kriteria & Klasifikasi & $\begin{array}{l}\text { Jumlah } \\
\text { (orang) }\end{array}$ & $\begin{array}{c}\text { Presentase } \\
(\%)\end{array}$ \\
\hline \multirow[t]{3}{*}{1.} & Jenis & Perempuan & 69 & 69 \\
\hline & Kelamin & Laki-laki & 31 & 31 \\
\hline & & Jumlah & 100 & 100 \\
\hline \multirow[t]{5}{*}{2.} & Usia & $18-22$ tahun & 81 & 81 \\
\hline & & 23-27 tahun & 13 & 13 \\
\hline & & 28-32 tahun & 4 & 4 \\
\hline & & $\geq 33$ tahun & 2 & 2 \\
\hline & & Jumlah & 100 & 100 \\
\hline \multirow[t]{5}{*}{3.} & Pendidikan & SMA/sederajat & 79 & 79 \\
\hline & Terakhir & Diploma & 11 & 11 \\
\hline & & Sarjana & 9 & 9 \\
\hline & & Pasca Sarjana & 1 & 1 \\
\hline & & Jumlah & 100 & 100 \\
\hline \multirow[t]{6}{*}{4.} & Pekerjaan & Mahasiswa/i & 76 & 76 \\
\hline & & Wiraswasta & 7 & 7 \\
\hline & & Karyawan Swasta & 15 & 15 \\
\hline & & PNS & 0 & 0 \\
\hline & & Lainnya & 2 & 2 \\
\hline & & Jumlah & 100 & 100 \\
\hline
\end{tabular}

Sumber: Data diolah, 2017

Berdasarkan pada Tabel 4, dilihat dari jenis kelamin, responden didominasi oleh perempuan sebanyak $69 \%$. Untuk usia responden didominasi pada rentang 18 22 tahun yaitu sebanyak $81 \%$. Untuk jenjang pendidikan, responden didominasi oleh rentang pendidikan minimal SMA/Sederajat sebesar 79\%. Dalam kategori pekerjaan, responden didominasi oleh mahasiswa sebesar $76 \%$. 
Instumen berupa kuesioner diuji menggunakan uji validitas dan reliabilitas, Uji validitas bertujuan untuk mengetahui ketepatan kuesioner, kuesioner dikatakan valid saat koefisien korelasi $\geq 0,3$. Uji reliabilitas bertujuan untuk mengetahui konsistensi kuesioner sebagai alat ukut. Kuesioner dikatakan reliable jika koefisien alpha cronbach $\geq 0,6$. Hasil dari uji validitas dan reliabilitas disajikan dalam Tabel 5, sebagai berikut:

Tabel 5. Hasil Uji Validitas dan Reliabilitas

\begin{tabular}{|c|c|c|c|c|}
\hline \multirow{2}{*}{ No. } & \multirow{2}{*}{ Variabel } & \multirow{2}{*}{ Inst. } & Uji Validitas & Uji Reliabilitas \\
\hline & & & Pearson Correlation & Cronbach Alpha \\
\hline \multirow{4}{*}{1.} & & $X_{.1}$ & 0,866 & \multirow{4}{*}{0,745} \\
\hline & Brand Image & $\mathrm{X} .2$ & 0,710 & \\
\hline & $(\mathrm{X})$ & $\mathrm{X} .3$ & 0,765 & \\
\hline & & X.4 & 0,686 & \\
\hline \multirow{3}{*}{2.} & & $Y_{1.1}$ & 0,820 & \multirow{3}{*}{0,816} \\
\hline & Brand Irust & $\mathrm{Y}_{1.2}$ & 0,908 & \\
\hline & & $\mathrm{Y}_{1.3}$ & 0,843 & \\
\hline \multirow{3}{*}{3.} & & $\mathrm{Y}_{2.1}$ & 0,792 & \multirow{3}{*}{0,780} \\
\hline & Brand Loyalty & $\mathrm{Y}_{2.2}$ & 0,862 & \\
\hline & & $\mathrm{Y}_{2.3}$ & 0,850 & \\
\hline
\end{tabular}

Sumber: Data diolah, 2017

Data dari Tabel 5, diketahui nilai koefisien korelasi semua indikator lebih besar dari 0,3 dan nilai dari cronbach alpha lebih besar dari 0,6. Hasil ini menunjukkan kuesioner yang digunakan merupakan instrumen yang layak untuk digunakan dan memiliki konsistensi yang baik.

Deskripsi jawaban responden mengenai variabel brand image, brand trust dan brand loyalty dapat diketahui melalui rata - rata skor jawaban dari kuesioner. Rata - rata tersebut digolongkan kedalam beberapa kelas interval dengan kategori sebagai berikut : $1,00-1,79=$ Sangat Tidak Baik ; 1,80 - 2,59= Tidak Baik ; 2,60 - 3,39 = Cukup Baik ; 3,40 - 4,19= Baik dan 4,20 - 5,00 = Sangat Baik. Deskripsi dari masing - masing variabel dijabarkan dalam Tabel 6 berikut, 
Tabel 6.

Deskripsi Jawaban Responden Terhadap Variabel Brand Image

\begin{tabular}{|c|c|c|c|c|c|c|c|}
\hline \multirow{2}{*}{ Pernyataan } & \multicolumn{5}{|c|}{ Proposi Jawaban Responden (\%) } & \multirow{2}{*}{$\begin{array}{c}\text { Rata- } \\
\text { rata }\end{array}$} & \multirow[t]{2}{*}{ Kriteria } \\
\hline & STS & TS & CS & $\mathbf{S}$ & SS & & \\
\hline $\begin{array}{l}\text { Saya merasa Iphone dapat } \\
\text { menciptakan kebanggaan bila saya } \\
\text { menggunakannya }\end{array}$ & 3,0 & 2,0 & 22,0 & 42,0 & 31,0 & 3,96 & Tinggi \\
\hline $\begin{array}{l}\text { Saya merasa Iphone memberikan } \\
\text { kemudahan dalam penggunaan } \\
\text { smartphone }\end{array}$ & - & 1,0 & 9,0 & 43,0 & 47,0 & 4.36 & $\begin{array}{l}\text { Sangat } \\
\text { Tinggi }\end{array}$ \\
\hline $\begin{array}{l}\text { Saya merasa Iphone dapat } \\
\text { meningkatkan kelas social } \\
\text { pengguna dimata masyarakat }\end{array}$ & 4,0 & 4,0 & 18,0 & 41,0 & 33,0 & 3,95 & Tinggi \\
\hline $\begin{array}{l}\text { Saya merasa Iphone memiliki } \\
\text { keunggulan dari segi desain } \\
\text { produknya }\end{array}$ & - & 1,0 & 5,0 & 40,0 & 54,0 & 4,47 & $\begin{array}{l}\text { Sangat } \\
\text { Tinggi }\end{array}$ \\
\hline \multicolumn{6}{|c|}{ Total } & 4,185 & Tinggi \\
\hline
\end{tabular}

Sumber: Data diolah, 2017

Variabel brand image, memiliki nilai skor rata-rata total yaitu sebesar 4,185.

Nilai tersebut masuk ke dalam kriteria tinggi, sehingga dapat dinyatakan bahwa secara umum responden memiliki persepsi yang baik terhadap brand image produk smartphone Iphone. Pernyataan "Saya merasa Iphone memiliki keunggulan dari segi desain produknya" diperoleh hasil rata-rata 4,47 yang termasuk dalam kriteria sangat tinggi.

Tabel 7.

Deskripsi Jawaban Responden Terhadap Variabel Brand Trust

\begin{tabular}{|c|c|c|c|c|c|c|c|}
\hline \multirow{2}{*}{ Pernyataan } & \multicolumn{5}{|c|}{ Proposi Jawaban Responden (\%) } & \multirow{2}{*}{$\begin{array}{c}\text { Rata- } \\
\text { rata }\end{array}$} & \multirow[t]{2}{*}{ Kriteria } \\
\hline & STS & TS & CS & $\mathbf{S}$ & SS & & \\
\hline \multirow{3}{*}{$\begin{array}{l}\text { Menurut saya Iphone merupakan } \\
\text { merek yang terpercaya } \\
\text { Saya merasa aman ketika } \\
\text { menggunakan produk Iphone } \\
\text { Menurut saya Iphone memberikan } \\
\text { kualitas yang sesuai dengan yang } \\
\text { dijanjikan }\end{array}$} & - & 1,0 & 2,0 & 37,0 & 60,0 & 4,56 & $\begin{array}{c}\text { Sangat } \\
\text { Tinggi }\end{array}$ \\
\hline & - & 4,0 & 9,0 & 38,0 & 49,0 & 4.32 & $\begin{array}{l}\text { Sangat } \\
\text { Tinggi }\end{array}$ \\
\hline & - & 2,0 & 4,0 & 46,0 & 48,0 & 4,40 & $\begin{array}{l}\text { Sangat } \\
\text { Tinggi }\end{array}$ \\
\hline \multicolumn{6}{|c|}{ Total } & 4,36 & $\begin{array}{c}\text { Sangat } \\
\text { tinggi }\end{array}$ \\
\hline
\end{tabular}

Sumber: Data diolah, 2017

Variabel brand trust, memiliki rata-rata total yaitu sebesar 4,36. Nilai tersebut masuk ke dalam kriteria sangat tinggi, secara umum responden memiliki persepsi 
E-Jurnal Manajemen Unud, Vol.-, No. -, 2018 :-

yang sangat baik terhadap brand trust produk smartphone Iphone. Pernyataan "Menurut saya Iphone merupakan merek yang terpercaya” memperoleh rata-rata 4,56 yang termasuk dalam kriteria sangat tinggi. Hal ini menunjukkan secara keseluruhan Iphone merupakan merek yang terpercaya.

Tabel 8.

Deskripsi Jawaban Responden Terhadap Variabel Brand Loyalty

\begin{tabular}{|c|c|c|c|c|c|c|c|}
\hline \multirow{2}{*}{ Pernyataan } & \multicolumn{5}{|c|}{ Proposi Jawaban Responden (\%) } & \multirow{2}{*}{$\begin{array}{c}\text { Rata- } \\
\text { rata }\end{array}$} & \multirow[t]{2}{*}{ Kriteria } \\
\hline & STS & TS & CS & $\mathbf{S}$ & SS & & \\
\hline $\begin{array}{l}\text { Saya menjadikan Iphone sebagai } \\
\text { pilihan pertama saya di pembelian } \\
\text { yang akan datang }\end{array}$ & - & 3,0 & 6,0 & 34,0 & 57,0 & 4,45 & $\begin{array}{l}\text { Sangat } \\
\text { Tinggi }\end{array}$ \\
\hline $\begin{array}{l}\text { Saya merekomendasikan merek } \\
\text { Iphone dan mengatakan hal-hal } \\
\text { positif tentang merek Iphone } \\
\text { kepada orang lain }\end{array}$ & - & 2,0 & 24,0 & 29,0 & 45,0 & 4.17 & Tinggi \\
\hline $\begin{array}{l}\text { Saya tidak akan membeli produk } \\
\text { smartphone lain selain merek } \\
\text { Iphone jika tersedia produk yang }\end{array}$ & 1,0 & 9,0 & 19,0 & 40,0 & 31,0 & 3,91 & Tinggi \\
\hline \multicolumn{6}{|c|}{ Total } & 4,17 & Tinggi \\
\hline
\end{tabular}

Sumber: Data diolah, 2017

Variabel brand loyalty, memiliki nilai skor rata-rata total yaitu sebesar 4,17.

Nilai tersebut masuk ke dalam kriteria tinggi, secara umum responden memiliki persepsi yang baik terhadap brand loyalty produk smartphone Iphone. Pernyataan "Saya menjadikan Iphone sebagai pilihan pertama saya di pembelian yang akan datang" memperoleh skor rata-rata 4,45 yang termasuk dalam kriteria sangat tinggi. Hal ini menunjukkan secara keseluruhan pengguna Iphone akan menjadikan Iphone sebagai pilihan pertamanya di pembelian yang akan datang.

Hasil uji analisis factor konfirmatori berupa measurement control, disajikan dalam Tabel 9, sebagai berikut:

Tabel 9.

Hasil Analisis Faktor Konfirmatori

\begin{tabular}{|c|c|c|c|c|c|c|}
\hline No. & tant & Indikator & KMO & Nilai & $\begin{array}{c}\text { Percentage of } \\
\text { Variance }\end{array}$ & $\begin{array}{c}\text { Loading } \\
\text { factor }\end{array}$ \\
\hline
\end{tabular}




\begin{tabular}{ccccccc}
\hline & & $\mathrm{X}_{\cdot 1}$ & & 0,642 & & \\
1. & $\mathrm{X}$ & $\mathrm{X}_{\cdot 2}$ & 0,643 & 0,647 & 66,513 & 0,840 \\
& & $\mathrm{X}_{\cdot 3}$ & & 0,592 & & 0,778 \\
& & $\mathrm{X}_{\cdot 4}$ & & 0,688 & & 0,757 \\
& & $\mathrm{Y}_{1.1}$ & & 0,733 & & 0,839 \\
2. & $\mathrm{Y}_{1}$ & $\mathrm{Y}_{1.2}$ & 0,700 & 0,655 & 73,683 & 0,893 \\
& & $\mathrm{Y}_{1.3}$ & & 0,727 & & 0,842 \\
& & $\mathrm{Y}_{2.1}$ & & 0,715 & & 0,823 \\
3. & $\mathrm{Y}_{2}$ & $\mathrm{Y}_{2.2}$ & 0,694 & 0,657 & 70,157 & 0,868 \\
& & $\mathrm{Y}_{2.3}$ & & 0,720 & & 0,820 \\
\hline
\end{tabular}

Sumber: Data diolah, 2017

Hasil uji KMO dalam Tabel 9 menunjukkan bahwa semua variabel memiliki nilai KMO yang lebih dari 0,5 . Berdasarkan hasil tersebut dapat disimpulkan ba hwa masing-masing variabel mempunyai kecukupan sampel untuk analisis faktor. Nilai MSA setiap instrumen lebih besar dari 0,5 yang artinya masing-masing model layak digunakan dalam analisis faktor. Hasil Percentage of Variance dari masingmasing faktor lebih besar dari 60 persen, sehingga variabel dalam kerangka telah layak untuk digunakan. Nilai loading factor indikator $\geq 0,50$ yang berarti seluruh indikator dalam penelitian memenuhi syarat untuk menjadikan indikator konstruk brand image, brand trust dan brand loyalty.

Hasil dari uji asumsi klasik ditemukan bahwa seluruh persamaan yang digunakan telah berdistribusi normal, sehingga persamaan telah lolos uji normalitas data. Pada uji multikoleniertas juga tidak terdapat gejala multikoliniar dari model regresi yang dibuat sehingga model ini layak digunakan untuk memprediksi. Nilai masing - masing signifikansi variabel lebih besar dari 0,05 , sehingga seluruh variabel yang digunakan bebas dari gejala heteroskedastisitas.

Hasil analisis jalur untuk persamaan 1 dan 2, disajikan dalam Tabel 10 dan 11, sebagai berikut:

Tabel 10.

Hasil Analisis Jalur Persamaan Regresi 1 
E-Jurnal Manajemen Unud, Vol.-, No. -, 2018 :-

\begin{tabular}{cccc}
\hline \multirow{2}{*}{ Model } & \multirow{2}{*}{ R Square } & Standardized Coefficients & \multirow{2}{*}{ Sig. } \\
\cline { 3 - 3 } & & Beta & 0,000 \\
\hline Brand Image & 0,346 & 0,589 & \\
\hline
\end{tabular}

Sumber: Data diolah, 2017

Berdasarkan hasil analisis jalur substruktural 1, maka diperoleh persamaan strukutral 1 adalah $\mathrm{Y}_{1}=0,589 \mathrm{X}+\mathrm{e}_{1}$

Tabel 11.

Hasil Analisis Jalur Persamaan Regesi 2

\begin{tabular}{cccc}
\hline \multirow{2}{*}{ Model } & \multirow{2}{*}{ R Square } & Standardized Coefficients & \multirow{2}{*}{ Sig. } \\
\cline { 3 - 3 } & 0,552 & Beta & 0,000 \\
Brand Image & 0,554 & 0,000 \\
Brand Trust & & 0,477 &
\end{tabular}

Berdasarkan hasil analisis jalur subtruktural 2, maka diperoleh pesamaan subtruktural 2 adalah $\mathrm{Y}_{2}=0,354 \mathrm{X}+0,477 \mathrm{Y}_{1}+\mathrm{e}_{2}$

Dari tabel 10 dan 11, diketahui nilai masing - masing $\mathrm{R}_{1}^{2}$ dan $\mathrm{R}_{2}^{2}$ adalah 0,346 dan 0,552 sehingga nilai error dapat dihitung menggunakan rumus e = $\sqrt{1-\mathrm{Ri}^{2}}$, nilai dari masing - masing error adalah 0,808 dan 0,669. Dari nilai error yang telah diketahui, maka selanjutnya dapat dihitung nilai koefisien determinasi total dengan rumus $\mathrm{R}^{2} \mathrm{~m}=1-\left(\mathrm{Pe}_{1}\right)^{2}\left(\mathrm{Pe}_{2}\right)^{2}$. Dar perhitungan koefisien determinasi diperoleh nilai sebesar 0,707 . Sehingga 70,7\% variasi brand loyalty dipengaruhi oleh variasi brand image dan variasi brand trust, sedangkan sisanya sebesar 29,3\% dijelaskan oleh faktor lain yang tidak dimasukkan ke dalam model.

Dari hasil pada Tabel 10 dan 11, diketahui nilai dari beta masing - masing variabel lebih besar dari pada 0 , dengan nilai signifikansi 0,000. Hal ini mengambarkan bahwa seluruh hipotesis yaitu $\mathrm{H}_{1}, \mathrm{H}_{2}$ dan $\mathrm{H}_{3}$ diterima dan $\mathrm{H}_{0}$ ditolak sehingga dapat disimpulkan bahwa brand image berpengaruh positif dan signifikan terhadap brand trust pada konsumen Iphone di Kota Denpasar, brand image 
berpengaruh positif dan signifikan terhadap brand loyalty pada konsumen Iphone di Kota Denpasar dan brand trust berpengaruh positif dan signifikan terhadap brand loyalty pada konsumen Iphone di Kota Denpasar.

Untuk pengaruh tidak langsung dan pengaruh total disajikan dalam Tabel 12, sebagai berikut:

Tabel 12.

Pengaruh Langsung dan Pengaruh Tidak Langsung serta Pengaruh Total Brand Image $(\mathrm{X})$, Brand Trust $\left(\mathrm{Y}_{1}\right)$ dan Brand Loyalty $\left(\mathrm{Y}_{2}\right)$

\begin{tabular}{cccc}
\hline $\begin{array}{c}\text { Pengaruh } \\
\text { Variabel }\end{array}$ & $\begin{array}{c}\text { Pengaruh } \\
\text { Langsung }\end{array}$ & $\begin{array}{c}\text { Pengaruh Tidak Langsung } \\
\text { Melalui Brand Trust }\end{array}$ & Pengaruh Total \\
\hline $\mathrm{X}_{1} \rightarrow \mathrm{Y}_{1}$ & 0,589 & - & 0,589 \\
$\mathrm{X}_{1} \rightarrow \mathrm{Y}_{2}$ & 0,354 & 0,281 & 0,635 \\
$\mathrm{Y}_{1} \rightarrow \mathrm{Y}_{2}$ & 0,477 & - & 0,477 \\
\hline Sumber: Data diolah, 2017 & &
\end{tabular}

Hasil pada tabel 12 dapat diketahui bahwa pengaruh langsung variabel brand image terhadap brand loyalty memiliki nilai koefisien beta sebesar 0,354 , sedangkan pengaruh tidak langsung yang dimediasi oleh brand trust menunjukkan nilai koefisien beta sebesar 0,281. Hasil ini membuktikan bahwa brand trust dapat memediasi pengaruh brand image terhadap brand loyalty dengan pengaruh total sebesar 0,635.

Hasil uji Sobel menunjukkan bahwa nilai koefisien $\mathrm{z}$ adalah 4,44 >1,96 dengan tingkat signifikansi $0,000<0,05$, sehingga $\mathrm{H}_{0}$ ditolak dan $\mathrm{H}_{1}$ diterima. Dari hasil tersebut dapat disimpulkan bahwa brand trust mampu memediasi hubungan brand image dengan brand loyalty.

Hipotesis $\mathrm{H}_{1}$ tentang pengaruh brand image terhadap brand trust pada konsumen Iphone di Kota Denpasar diterima, hal ini menunjukkan bahwa brand image secara positif dan signifikan berpengaruh terhadap brand trust pada konsumen Iphone di Kota Denpasar. Hal tersebut berarti bahwa semakin baik brand 
E-Jurnal Manajemen Unud, Vol.-, No. -, 2018 :-

image yang dibentuk oleh suatu merek terhadap konsumen maka semakin tinggi brand trust yang dirasakan konsumen terhadap merek tersebut. Hasil penelitian ini mendukung temuan Bastian (2014), Alhaddad (2015) dan Richard Chinomona (2016) yang memperoleh hasil brand image berpengaruh positif dan signifikan terhadap brand trust.

Hipotesis $\mathrm{H}_{2}$ tentang pengaruh brand image terhadap brand loyalty pada konsumen Iphone di Kota Denpasar diterima, hal ini menunjukkan bahwa brand image secara positif dan signifikan berpengaruh terhadap brand loyalty pada konsumen Iphone di Kota Denpasar. Hal tersebut berarti bahwa semakin baik image yang dibentuk oleh suatu merek terhadap konsumen maka semakin tinggi loyalitas yang dirasakan konsumen terhadap merek tersebut. Hasil penelitian ini mendukung temuan De Nischay, Prof. Chanda, dan Dr. Garima (2014), Dewi dan Suasana (2014), Saputri dan Pranata (2014) dan Salim dan Dharmayanti (2014) yang memperoleh hasil brand image berpengaruh positif dan signifikan terhadap brand loyalty.

Hipotesis $\mathrm{H}_{3}$ tentang pengaruh brand trust terhadap brand loyalty pada konsumen Iphone di Kota Denpasar diterima, hal ini menunjukkan bahwa brand trust secara positif dan signifikan berpengaruh terhadap brand loyalty pada konsumen Iphone di Kota Denpasar. Hal tersebut berarti bahwa semakin tinggi kepercayaan yang dibentuk oleh suatu merek terhadap konsumen maka semakin tinggi loyalitas konsumen terhadap merek tersebut. Hasil penelitian ini mendukung temuan Kabadayi (2012), Geçti dan Zengin (2013), Ahmed et al. (2014) dan Putra 
(2014) memperoleh hasil brand trust berpengaruh positif dan signifikan terhadap brand loyalty.

Hipotesis $\mathrm{H}_{4}$ tentang peran brand trust dalam memediasi hubungan brand image dengan brand loyalty pada konsumen Iphone di Kota Denpasar diterima, hal ini menunjukkan bahwa brand trust secara positif dan signifikan mampu memediasi brand image dengan brand loyalty pada konsumen Iphone di Kota Denpasar. Hal tersebut berarti bahwa kepercayaan yang kuat dibentuk oleh suatu merek terhadap konsumen mampu meningkatkan image suatu merek terhadap tingginya loyalitas konsumen terhadap merek tersebut. Hasil penelitian ini mendukung temuan SB. Handayani dan Ida Martini (2015) memperoleh hasil brand trust mampu memediasi hubungan brand image dengan brand loyalty.

Implikasi dari hasil penelitian ini menekankan pada manfaat nyata dalam menimbulkan loyalitas bagi konsumen Iphone. Implikasi hasil penelitian yang didapat yaitu pertama dari sisi brand image, kedepannya Iphone harus melakukan pemasaran campaign (iklan) yang maksimal dan inovatif untuk menunjang image kelas sosial di mata masyarakat. Hal tersebut dapat dilakukan dengan penggunaan celebrity endorser yang menarik minat dan menimbulkan image yang tinggi bagi Iphone sehingga image Iphone yang berkelas dapat dirasakan bagi penggunanya di mata masyarakat. Kedua, berhubungan dengan brand trust kedepannya ditumbuhkan dari sisi kemananan pengguna Iphone terhadap basis data didalam smartphone itu sendiri, yaitu pemaksimalan penggunaan iCloud sebagai basis backup data beserta kode-kode keamanan data pengguna. Ketiga, menciptakan loyalitas merek, kepercayaan terhadap Iphone tidak membuat pelanggan bersedia 
E-Jurnal Manajemen Unud, Vol.-, No. -, 2018 :-

mengulang membeli merek ini. Kepercayaan harus secara terus menerus dibangkitkan dan didorong, dengan berbagai strategi pemasaran yang unik dan menarik. Konkritnya membuat program promosi yang tepat dan agresif, yaitu loyalty program. Program loyalitas ini sebagai bentuk kerjasama yang dilakukan dengan perusahaan bank dan perusahaan kartu seluler tertentu yang memberikan kebijakan harga yang kompetitif sehubungan dalam pembeliaan produk Iphone dan membangun jaringan distribusi yang lebih efektif. Ini semua dilakukan agar konsumen Iphone kedepan menjadi lebih loyal dan tidak mudah beralih ke merek lain

\section{SIMPULAN DAN SARAN}

Berdasarkan hasil pembahasan penelitian yang telah dilakukan, maka dapat disimpulkan bahwa: brand image secara positif dan signifikan berpengaruh terhadap brand trust pada konsumen Iphone di Kota Denpasar. Hal tersebut berarti bahwa semakin baik brand image yang dibentuk oleh suatu merek terhadap konsumen maka semakin tinggi brand trust yang dirasakan konsumen terhadap merek tersebut.

Brand image secara positif dan signifikan berpengaruh terhadap brand loyalty pada konsumen Iphone di Kota Denpasar. Hal tersebut berarti bahwa semakin baik image yang dibentuk oleh suatu merek terhadap konsumen maka semakin tinggi loyalitas yang dirasakan konsumen terhadap merek tersebut.

Brand trust secara positif dan signifikan berpengaruh terhadap brand loyalty pada konsumen Iphone di Kota Denpasar. Hal tersebut berarti bahwa semakin 
tinggi kepercayaan yang dibentuk oleh suatu merek terhadap konsumen maka semakin tinggi loyalitas konsumen terhadap merek tersebut.

Brand trust secara positif dan signifikan mampu memediasi brand image dengan brand loyalty pada konsumen Iphone di Kota Denpasar. Hal tersebut berarti bahwa kepercayaan yang kuat dibentuk oleh suatu merek terhadap konsumen mampu meningkatkan image suatu merek terhadap tingginya loyalitas konsumen terhadap merek tersebut.

\section{Saran}

Berdasarkan hasil analisis dan simpulan, maka saran-saran yang dapat diberikan kepada perusahaan diantaranya, perusahaan harus melalukan pemasaran campaign (iklan) yang maksimal dan inovatif untuk menunjang image kelas sosial di mata masyarakat. Peusahaan harus meningkatkan kepercayaan konnsumen terhadap keamanan produknya. Dalam mempertahankan konsumen loyalnya, perusahaan harus membuat program promosi yang tepat dan agresif, berupa loyalty program.

Saran bagi akademins berupa kedepannya dapat melakukan penelitian di tempat yang berbeda dan juga memperluas cakupan wilayah penelitian. Peneliti selanjutnya hendaknya mengembangkan penelitian ini dengan mengambil faktorfaktor lain diluar variabel-variabel yang diteliti, misalnya brand effect, customer satisfaction. Penelitian hendaknya dilakukan pada satu jenis smartphone Apple yang terbaru sehingga penelitian menjadi lebih spesifik

\section{REFERENSI}


E-Jurnal Manajemen Unud, Vol.-, No. -, 2018 :-

Aaker, David. 1991. Managing Brand Equity; Capitalizing on the Value of Brand Name. New York: Free Press

Ahmed, Zohaib, Muhammad Rizwan, Mukhtar Ahmad, dan Misbahul Haq. 2014. Effect of Brand Trust and Customer Satisfaction on Brand Loyalty in Bahawalpur. Journal of Sociological Research, 5 (1), pp: 306-326

Alhaddad, Abdullah. 2015. A Structural Model of The Relationships Between Brand Image, Brand Trust and Brand Loyalty. International Journal of Management Research \& Review, 5 (1), pp: 137-144

Andreani, Fransisca, Tan Lucy Taniaji and Ruth Natalia Made Puspitasari. 2012. The Impact of Brand Image, Customer Loyalty with Customer Satisfaction as A Mediator in Mcdonald's. Jurnal Manajemen dan Kewirausahaan, 14 (1), h: 63-70

Bastian, Danny Alexander. 2014. Analisa Pengaruh Citra Merek (Brand Image) dan Kepercayaan Merek (Brand Trust) Terhadap Loyalitas Merek (Brand Loyalty) ADES PT. Ades Alfindo Putra Setia. Jurnal Manajemen Pemasaran Petra, 2 (1), h: $1-9$

Barnes, James G. 2003. Secrets of Customer Relationship Management. Yogyakarta: Penerbit Andi

Chaudhuri, Arjun dan Morris B. Holbrook. 2001. The Chain of Effects from Brand Trust and Brand Affect to Brand Performance: The Role of Brand Loyalty. Journal of Marketing, 65 (2), pp: 81-93

Chinomona, Richard. 2016. Brand Communication, Brand Image and Brand Trust as Antecedents of Brand Loyalty in Gauteng Province of South Africa. African Journal of Economic and Management Studies, 7 (1), pp: 124 - 139

Delgado, Elena, Maria Jesus Yague-Guillen dan Jose Luis Munuera-Aleman. 2003, Development and Validation of a Brand Trush Scale, International Journal of Market Research, 45 (1), pp: 35-34.

Detiknet. 2015. 59\% Pengguna Internet Indonesia Ada di Jawa \& Bali. (https://inet.detik.com/cyberlife/d-2886207/59-pengguna-internet indonesiaada-di-jawa--bali, diakes pada tanggal 21 Maret 2017) .

Dewi, Ni Nyoman Ayu Suri Tri Cahyaning dan I Gusti Agung Ketut Gede Suasana. 2014. Pengaruh Kualitas Produk, Citra Merek, Dan Materialisme Terhadap Loyalitas Merek Pengguna Produk Apple Di Kota Denpasar. E-Jurnal Manajemen Universitas Udayana, 3 (3), h: 714-732.

Ferdinand, A. 2002. Structural Equation Modeling dalam Penelitian Manajemen: Aplikasi Model-model Rumit dalam Penelitian untuk Tesis Manajemen. Semarang: UNDIP. 
Geçti, Fatih dan Hayrettin Zengin. 2013. The Relationship between Brand Trust, Brand Affect, Attitudinal Loyalty and Behavioral Loyalty: A Field Study towards Sports Shoe Consumers in Turkey. International Journal of Marketing Studies, 5 (2), pp: 111-119

Ghozali, Iman. 2013. Aplikasi Analisis Multivariate dengan Program IBM SPSS 21. Cetakan Ketujuh. Semarang: Badan Penerbit Universitas Diponegoro

Gibson. 2005. Perilaku Organisasi.Edisi Terjemahan Ke-10. Jakarta: PT. Indeks

Griffin, Jill. 2005. Customer Loyalty: Menumbuhkan dan Mempertahankan Kesetiaan Pelanggan. Jakarta: Erlangga.

Hadi, Prasetyo dan Sumarto. 2010. Pentingnya Brand Loyalty Terhadap Minat Beli Ulang. Jurnal Riset Ekonomi dan Bisnis, 10 (1), pp: 9-18

Handayani, SB dan Ida Martini. 2015. Pengaruh Brand Image Terhadap Brand Loyalty Brand Trust sebagai Variabel Mediasi (Studi Empiris Pada Pemakai Motor Matic Merek Yamaha di Kota Semarang). PPJM (Perkumpulan Pengelola Jurnal Manajemen) Management Dynamic Conference - MADIC National Seminar and Call for Paper 2015, 1

Harnoto, Fasoschah. 2013. Analisis Pengaruh Kepercayaan dan Kualitas Layanan terhadap Loyalitas Pelanggan dengan Kepuasan Konsumen Sebagai Variabel Mediasi (Studi Pada RS Darul Istiqomah Kaliwungu Kendal). Jurnal ekonomi Manajemen Akutansi, 34 (20), h: 1-23

Iskandar. 2016. 7 Kelebihan Iphone Dibanding Android, Dari Desain hingga Software (http://tekno.liputan6.com/read/2489828/7-kelebihan-Iphone diban ding-android-dari-desain-hingga-software, diakses pada tanggal 8 April 2017)

Kabadayi, Ebru Tümer dan Alev Koçak Alan. 2012. Brand Trust and Brand Affect: Their Strategic Importance on Brand Loyalty. Journal of Global Strategic Management, 6 (1), pp:81-89

Keller, Kevin Lane. 1993. How to Manage Brand Equity. Jakarta: Gramedia Pustaka

Kotler, Philip dan Kevin Lane Keller. 2009. Manajemen Pemasaran Jilid 1, edisi ke-13. Jakarta: Erlangga

Kotler, Philip. 2002. Manajemen Pemasaran Jilid 1. Edisi Milenium. Jakarta: Prehallindo

Kotler, Phillip dan Gary Amstrong. 2001. Prinsip-Prinsip Pemasaran. Jilid 2 edisi ke-8. Jakarta: Penerbit Erlangga 
Kustini, Nuruni Ika. 2011. Experiential Marketing, Emotional Branding, and Brand Trust and Their Effect on Loyalty on Honda Motorcycle Product. Journal of Economics, Business and Accountancy Ventura, 14 (1), pp: 19 - 28

Lau, Geok Then and Sook Han Lee. 1999. Costumers Trust in a Brand and the Link to Brand Loyalty. Journal of Market Focused Management. 4, pp:341-347

Maliyah, Siti. 2015. Pengaruh Citra Merek, Kepercayaan (Trust) dan Komitmen terhadap Loyalitas Nasabah pada PT. Henan Putihrai Asset Management. Jurnal Ilmiah Manajemen dan Bisnis, 1(1), h: 9-21

Mohammad. 2012. The Effect of Brand Trust and Perceived Value in Building Brand Loyalty. International Research of Journal of Finance and Economic. 85, pp: 111-126.

Morgant, Robert M dan Shelby D Hunt. 1994. The Commitment- Trust Theory of Relationship Marketing. Journal of Marketing. 58, pp: 20-38

Natarajan, Dr. R dan V. Sudha. 2016. A Relationship Between Brand Image and Brand Loyalty (A Study with Reference to FMCG Costumers in Vollure District). EPRA International Journal Economic and Business Review. 4 (5), pp: $130-145$

Noor, Mitha Fadilla. 2014. Pengaruh Brand Image dan Brand Trust Terhadap Brand Loyalty King Thai Tea Bandung. Electronic Journal of Indonesia University of Educa ton, 3(2), h: 127-140

Putra, Bariocha Benaya Brendana dan Eka Sulistyawati. 2014. Peran Loyalitas Produk Telepon Pintar Merek Apple di Kota Denpasar. E-Jurnal Manajemen Universitas Udayana, 3 (9), h: 2578-2596

Rizan, Mohammad, Basrah Saidani, dan Yusiyana Sari. Pengaruh Brand Image dan Brand Trust Terhadap Brand Loyalty Teh Botol Sosro (Survei Konsumen Teh Botol Sosro di Food Court ITC Cempaka Mas, Jakarta Timur). Jurnal Riset Manajemen Sains Indonesia (JRMSI), 3 (1), h: 1-17

Salim, Fanny Fibriyanti dan Diah Dharmayanti, S.E., M.Si. 2014. Pengaruh Brand Image dan Perceived Quality Terhadap Kepuasan dan Loyalitas Pelanggan Mobil Toyota di Surabaya. Jurnal Manajemen Pemasaran Petra. 2 (1), h: 1-8.

Saputri, Marheni Eka dan Tutut Ratna Pranata. 2014. Pengaruh Brand Image Terhadap Kesetiaan Pengguna Smartphone Iphone. Jurnal Sosioteknologi Institut Teknologi Bandung, 13 (3), h: 193-201

Satyadharma, Arsi Artisti. 2014. Pengaruh Kepuasan Pelanggan Terhadap Kepercayaan Merek, Loyalitas Merek dan Ekuitas Merek Mi Instan Indomie di Surabaya. Jurnal Ilmiah Manajemen Universitas Surabaya, 3 (1), h: 1-19 
Sibagariang, Sem Christina Hawila dan Tinjung Desy Nursanti. 2010. Pengaruh Brand Image Dan Brand Trust Terhadap Brand Loyalty Pada PT Bank Sinarmas. Journal The WINNERS, 11(2), h: 118-129

Sirdeshmukh, Deepak, Jagdip Singh, dan Barry Sabol. 2002. Costumer Trust, Value, and Loyalty in Relational Exchanges. Journal of Marketing. 66 (1), pp: $15-37$

Sondoh Jr, Stephen L., Maznah Wan Omar, Nabsiah Abdul Wahid, Ishak Ismail dan Amran Harun. 2007. The Effect of Brand Image on Overall Satisfaction and Loyalty Intention in The Context of Color Cosmetic. Asian Academy of Management Journal, 12 (1), pp: 83-107

Sugiyono. 2016. Metode Penelitian Adminstrasi. Bandung: Penerbit Alfabeta

Tjahyadi, Arlan dan Rully. 2006. Brand Trust Dalam Konteks Loyalitas Merek: Peran karakteristik Merek, Karakteristik Perusahaan Dan Karakteristik Hubungan Pelanggan-Merek. Jurnal Manajemen, 6 (1), h: 65-78

Upamanyu, Dr. Nischay K, Prof. Chanda Gulati, dan Dr. Garima Mathur. 2014. Effect of Brand Trust, Brand Image on Customer Brand Loyalty in FMCG Sector at Gwalior Region. Scholars World - International Refereed Multidisciplinary Journal of Contemporary Research, 2 (2), pp: 83-93

Wahyudi, Ade. 2017. Indonesia, Raksasa Teknologi Digital Asia. (http://databoks.katadata.co.id/datablog/2017/01/24/indonesia-raksasateknologi-digital-asia, diakses pada tanggal 21 Maret 2017)

Yusuf, Oik. 2013. Mengapa Pengguna Iphone Lebih Loyal dari Android? (http://tekno.kompas.com/read/2013/08/26/1637479/Mengapa.Pengguna.Ipho ne.Lebih.Loyal.dari.Android, diakses pada tanggal 8 April 2017) 